\title{
The Paradox of Women as Victims in the selected plays of Tennessee Williams and Vijay Tendulkar
}

\author{
Aishwarya Mohan
}

Department of English, University of Madras, Chennai, India

Received: 09 Apr 2021; Received in revised form: 01 May 2021; Accepted: 19 May 2021; Available online: 06 Jun 2021 (C)2021 The Author(s). Published by Infogain Publication. This is an open access article under the CC BY license (https://creativecommons.org/licenses/by/4.0/).

\begin{abstract}
This paper will analyze the key women characters in Vijay Tendulkar's Silence! The Court is in Session, Tennessee Williams'A Street Car named Desire and The Glass Menagerie. Williams and Tendulkar share certain similar traits in representing the middle-class lifestyle, the innate character of humans, especially with women's desire, space and oppression. The lead women characters that this paper will focus on include Miss. Benare, Blanche DuBois, Amanda Wingfield and Laure Wingfield. Both the playwrights use techniques like game, trap, reversal and violence in their plays. Neither all the protagonistic women characters in the plays exhibit attention for pity, nor they are dependent or submissive. How can women with endurance, passion, courage be categorized a victim? They are bold, independent and possess no traits of a victim except their gender. Williams and Tendulkar sculpted their women characters with complexity. They are paradoxical - independent yet trapped, unremitting yet victimized, passionate yet restricted, admirable yet pitied. Laura and Amanda are indeed quite different from Benare and Blanche. While Laura and Amanda find solace retiring into their imagination, Blanche and Benare struggle with the sordid reality. Unanimously all women characters remain contented in their "women's space" - a space where a woman is at her liberty with her own body, thoughts and emotions. The current paper will further delve into the reasons behind the relationship the women victims establish with their male victimizers.
\end{abstract}

Keywords-Illusion, Paradox, Patriarchal intrusion, Victim, Women's space

\section{INTRODUCTION}

Tennessee Williams and Vijay Tendulkar were contemporary playwrights of the 20th century. Their works also echoed similar themes of the brutal nature of humans, sexuality, violence, middle-class attitude and morality. Williams and Tendulkar used the same techniques like symbolism, reversal and metaphor in their plays to bring out the grim reality that life holds. Thomas Alder, in his The Moth and the Lantern, points out that Williams' early criticisms focused on three major problems, "the potentially shocking nature of Williams' material, the seemingly loose way in which he structured it, and the apparently pessimistic stance he took toward human existence"(Adler, p. 11).

IJELS-2021, 6(3), (ISSN: 2456-7620)

https://dx.doi.org/10.22161/ijels.63.28
In Silence! The Court is in Session, Miss. Benare, at the beginning of the play, remains optimistic, dominant, enthusiastic and independent, but in the end, she is silent or perhaps silenced by the 'patriarchal game'. This play of Tendulkar unfurls the life of Miss. Benare, her love for Professor Damle (a married man with three children) and the child in her womb fathered by Professor Damle. Benare becomes exhausted of emotions and flushed with hopelessness. Men in the play, act as a witness to Benare's personal life and thereby intruding into her women's space, in the guise of playing a game. In an interview with Gowri Ramnarayan, Tendulkar acknowledges the complex issues his plays address, "Man is a complex phenomenon; any attempt at simplification through generalization would be foolish. I fear it also falsifies the picture. I wouldn't do 
that. It's an obsession with me to capture human behaviour, elusive and ever changing. At every stage, what I perceived has been reflected in my work."

Williams'A Streetcar Names Desire portrays Blanche DuBois, a wealthy Southern woman who arrives in New Orleans to stay at her sister's house. Blanche lost her house Belle Reve to the creditors and her job for her involvement with a student in the school where she worked. With nowhere to go, she arrives at Stella and Stanley's house. Blanche has undergone a nervous breakdown and a lot of stress due to her past endeavours. At Stella's home, she sees Mitch, a friend of Stanley's, reciprocated the love that Blanche has yearned for all her life. To Blanche's dismay, Mitch rejects her when he gets to know Blanche's past despite her plea for forgiveness and confession. At the end of the play, Stanley sexually assaults her, which results in a severe mental breakdown in Blanche. She is victimized, silenced, made helpless that even Stella is not ready to believe Blanche's statement that Stanley has assaulted her sexually.

The Glass Menagerie is quite different compared to the two other plays. Amanda and Laura hibernate into their world of imagination and dreams. Amanda's adherence to her past and Laura's attachment with her glass menagerie restrict them from facing reality or a vent for the mother and the daughter from the hardships of reality. In Silence! The Court is in Session, and The Glass Menagerie, the absent presence of Professor Damle and Mr. Wingfield create a tremendous difference. The linchpins behind the suffering of Benare, Amanda and Laura are not physically present in the drama, but their psychological presence torments the women throughout the plays.

\section{WOMEN'S SPACE}

"There is a battle sometimes, where Defeat is destined as the end" (Tendulkar, 1978, p. 10). In the selected plays, all the women characters face patriarchal oppression, and they battle for their rights and liberty, knowing well what is impending, their defeat. A warrior who goes to the battlefield with the foreknowledge that he will be defeated expresses his sheer courage. These women, too, are representatives who display their struggles in their way to their liberty against oppression. The plays reflect neither their victory nor their destination but the journey they undertake for themselves. Though confined, Benare, Blanche, Amanda and Laura feel immensely contented with their true selves. The male characters in the plays take control of the unravelling of the plot and its actions. Tom Wingfield and Mr. Wingfield tried to escape from their familial duties. They did not suppress or enforce violence on neither Amanda nor Laura, but it was psychological. Mr. Wingfield's abandoning the family made Amanda enduring as well as dependent on Tom for financial assistance. Monetary needs become an instrument for men through whom the society ensures placing women in a dependent state.

Patriarchy liberates women from their suppressive presence yet restraining them into a world of dependence, and later, Tom, too follows his father's footsteps. Amanda and Laura create their private space in their imagination. Laura feels comfortable and happy in her world of the glass menagerie until an intrusion by Jim O' Connor. Laura feels anew in the presence of Jim, but in the end, she is again left alone in her world of loneliness. On remembering Mr. Wingfield, Amanda says, "Eternally play those worn-out phone graph records your father left as a painful reminder of him?" The photograph of Wingfield and the record player remain an eternal painful memory for Amanda. Closely, the actions of Tom and Jim O' Connor will remain a painful memory for Amanda and Laura. Mr. Wingfield's conspicuous presence instils terror in Amanda whenever she mentions him to Tom. It is the nostalgic past that Amanda ruminates on gives some happiness to her.

Benare and Blanche are drawn much into reality, unlike Amanda and Laura. Benare unconsciously touches her stomach, where her baby resides, to enjoy the pleasure of motherhood and considers the child as an outcome of her love for Damle. She becomes devastated when $\mathrm{Mr}$. Kashikar, the judge in the mock trial, passed a judgment that the baby must be aborted as it is a sin to become pregnant before marriage. Benare even imagines living happily with her child, and she affirms that her life is her own and happy when left alone with her dreams and life. "My life is my own. I haven't sold it to anyone for a job! My will is my own. My wishes are my own...I like with myself and my life! I'll decide" (Tendulkar, 1978, p. 5)

Benare and Blanche have witnessed betrayal in the past, rooting their dreams in the future - the former on her baby and the latter on Mitch. Their hopes and dreams in the past and for the future become a nightmare on the intrusion by men around them. Patriarchy is unable to stand women's hope, dreams, and independence. In Silence! The Court is in Session, Benare's character contrasts Mrs. Kashikar's role. Mrs. Kashikar symbolizes the traditional traits that a woman must have obedience, loyalty, dependent, and submissive. Blanche and Benare want to live their lives to the fulfilment of their dreams and desires, but to their dismay, the path to their destination is neither easy nor achieved. Both Blanche and Benare, at the end of the play, exhibit some mental disorder, and they yield to the men around them, or that is 
how both the plays end. Despite their strong characterization, the end that befalls them is paradoxical.

\section{PATRIARCHAL INTRUSION}

Stanley: Delicate piece she is.

Stella: She is. She was...Nobody, nobody, was tender and trusting as she was. But people like you abused her, and forced her to change" (Williams, 1947, p. 128)

As Philip Weissman observes in his essay "A Trio of Tennessee Williams' Heroines: The Psychology of Prostitution", Blanche's past has immensely shaped her present. Though she possesses an independent spirit, she is the "representative of the sensitive individual lost in the complex, impersonal modern world." Weisman says, "Blanche DuBois' fear of loneliness and abandonment is probably based on a disturbance of early object relationship, in which she differs intensely from her sister Stella. This accounts for her incapacity to establish a permanent object relationship..." The world becomes complex for her when she encounters the animal that resides in every man. Not only Blanche but also Benare, Amanda, and Laura have men who intrude into their independent spirit. Despite her past traumas with men, Blanche wishes to have a male companion for support and security. In Williams and Tendulkar's worlds, a woman who stands alone without support from a man becomes a prey.

As Anca Vlasopolos argues in her essay, "Authorizing History: Victimization in A Streetcar Named Desire," the history of the South is of less importance than the issue of gender exclusion in the historical discourse. She sees Stanley as a representative who reestablishes order, authority and confines women to their spaces. Men around Benare curb her wings to restrict her within the patriarchal limits of society. Tom and his father's abandonment make Amanda and Laura deeply realize their state of dependency and support from men.

In "Tennessee Williams and the tragedy of Sensitivity" by John T. von Szeliski, von Szeliski points out, "Williams' heroes strive for but cannot make successful adjustments to this kind of life-problem without becoming animals themselves" (Miller, 1971, p. 66). This observation applies to all the male characters in The Glass Menagerie, A Streetcar Named Desire and Silence! The Court is in Session. This animosity comes out especially concerning women who place themselves out of all the social norms. In The Glass Menagerie, the animosity exerted on Laura and Amanda is more psychological than physical. Witnessing a woman independent brings out the animosity in men, which lead to their intrusion into a woman's space, making them vulnerable and dependent. In the end, Benare admits this, "Whoever you are-I have always depended on the kindness of strangers" (Williams, 1947, p. 165).

Amanda's encounter with men is different as she represents the future versions of Benare and Blanche in many ways. The trauma that men caused to Blanche and Benare will have its consequences psychologically as Amanda has her own with Mr. Wingfield. Amanda aspires to live the rest of her life for her children after the abandonment of her husband and so Benare. Tom turns out to be the psychological double of his father, and there is a fair chance of Benare giving birth to a boy who may have the animosity that his father possessed. Women were caught in this eternal cycle in search of unbiased love and support. The core of this becomes the epigraph of Williams' A Streetcar Named Desire from "The Broken Tower" by Hart Crane - "And so it was I entered the broken world, To trace the visionary company of love..."

\section{CONCLUSION}

The paper tried to focus on the paradoxical nature of women as victims in Vijay Tendulkar's Silence! The Court is in Session, Tennessee Williams' A Streetcar Named Desire and The Glass Menagerie. At its core, it reflected on the innate nature of courage, determination and perseverance that the women characters exhibit contrasted with the sadistic, gloomy end that these women were made to met with in their lives. Benare, Amanda and Benare were aware that the battle they were fighting would end and that they will lose to the established institution but they did not yield in. The paradox is that they are labelled as victims, and this is one of the many complexities that Williams and Tendulkar's plays put forth.

Anca Vlasopolos' seminal essay, "Authorizing History: Victimization in A Streetcar Named Desire", denies the majority of the critics' assumption of Blanche's death after the end of the play. However, she argues, the effect of the scar that the animosity of Stanley subjected on Blanche will continue to live. "Some things are not forgivable. Deliberate cruelty is not forgivable. It is the most unforgivable thing in my opinion, and the one thing in which I have never, ever been guilty" (Williams, 1947, p. 146). Blanche remains guilt-free, as she has not exerted deliberate cruelty on anybody as Stanley has done; similarly, Benare, Laura and Amanda, too, have not run like cowards after they scratched someone to bleed. "They don't scratch you till you bleed, then run away like cowards" (Tendulkar, 1978, p. 4). Men remain as a medium of an institution through which both subjugate 
women and intrude into their space to show the animosity that most possess.

\section{REFERENCES}

[1] ADLER, Thomas P. 1990. A Streetcar Named Desire: The Moth and the Lantern. Twayne Publishers.

[2] MILLER, Jordan Y. 1971. (ed.). Twentieth Century Interpretations of A Streetcar Named Desire. Prentice Hall.

[3] Tendulkar, Vijay. 1978. Silence! The court is in session. Oxford University Press

[4] Vlasopolos, Anca. 1986. "Authorizing History: Victimization in A Streetcar Named Desire". Theatre Journal, 38(3), 322-338. doi:10.2307/3208047

[5] Von Szeliski, John T. "Tennessee Williams and the Tragedy of Sensitivity," in MILLER, Twentieth Century Interpretations.

[6] Weissman, P. (1960). Psychopathological Characters in Current Drama A Study of a Trio of Heroines. American Imago, 17(3), 271-288. Retrieved May 20, 2021, from http://www.jstor.org/stable/26301740

[7] Williams, Tennessee. 1947. A Streetcar Named Desire. New Directions Books.

[8] ---.1944. The Glass Menagerie. Surjeet Publications 